\title{
OS ESTUDOS SOBRE ORIENTE MÉDIO E MUNDO MUÇULMANO NO BRASIL NOS ÚLTIMOS 15 ANOS II: ENTRE O DEBATE CLÁSSICO E OS TEMAS CONTEMPORÂNEOS.
}

\author{
Peter Robert Demant \\ Ariel Finguerut
}

A Revista Malala em seu oitavo número finaliza uma edição especial em duas publicações que se propuseram a fazer um balanço contemporâneo dos estudos sobre Oriente Médio e mundo muçulmano no Brasil.

Neste segundo número especial destacamos dois grupos relativamente bem delimitados de trabalhos. No primeiro grupo podemos alocar as produções que se propõem ao difícil e necessário debate sobre como estudar este objeto, quais são os caminhos possíveis, os desafios e peculiaridades de se fazê-lo no Brasil. Neste sentido, nossa entrevista com a professora da Universidade de Brasília, Norma Breda dos Santos, destaca o esforço e toda riqueza que a pesquisa documental em arquivos pode proporcionar. Breda destaca a relevância para o debate brasileiro dos trabalhos que passaram pelo crivo de uma cuidadosa e bem feita pesquisa em arquivos. Marcos Alan S. V. Ferreira faz uma resenha de um clássico sobre Oriente Médio e Mundo Muçulmano, Uma História dos Povos Árabes de Albert Hourani, uma obra que influenciou gerações de pesquisadores brasileiros. Nesta revisão, Ferreira discute conceitos do mundo árabe que lhe confeririam unidade - inclusive para podermos falar em "Mundo Árabe" - e pondera algumas discussões clássicas como a relação com a democracia, com o elitismo e o papel da língua árabe dentro do que chamamos de "Mundo Muçulmano".

Ainda neste grupo de "debates clássicos", Eliceli Katia Bonan e Mariana Faiad B. Alves discutem dois conflitos históricos e até hoje centrais para entendermos o Oriente Médio e Mundo Muçulmano. Eliceli apresenta sua pesquisa fruto de um trabalho de campo sobre o conflito Israel-Palestina, apresentando relatos de ativistas e pessoas próximas a movimentos de paz de ambos os lados. O relato de viagem também conta com um rico material fotográfico de arquivo pessoal da autora. Não menos central para o Oriente Médio e Mundo Muçulmano, o conflito Índia-Paquistão é tema da contribuição de Mariana Faiad B. Alves. No artigo, a autora nos mostra que apesar de muitas vezes associamos o fundamentalismo religioso apenas ao islã, a radicalização religiosa hindu e a violência identitária são centrais para entendermos conflitos sectários numa das regiões mais populosas do mundo.

Num segundo grupo de textos, é possível alocar aqueles autores que buscam alguma maior inserção no debate contemporâneo. Marília Valério Rocha discute a experiência docente ao propor o estudo da geometria do mundo muçulmano no curso de Engenharia 


\section{apresentação}

Civil. A experiência foi bem sucedida e mostra a necessidade de se ter - e aumentar a diversidade e transdisciplinaridade na formação universitária brasileira. Também discutindo diversidade, Leandra Elena Yunis debate as possibilidades imaginárias diante da cultura a partir da tradução direta e inédita para o português de um gazal de Jalaluddin Rumi, poeta persa do século XIII. A autora inova ao conceder centralidade ao conceito sufi de unicidade e trazer os elementos da dança, da música e da poesia para transmutação corpórea, elevação e autodomínio.

Mostrando novas perspectivas para debates contemporâneos, Flávia X. M. Paniz, ao debater o filme marroquino Much Loved, mostra como as discussões sobre sexualidade no islã são difíceis e muitas vezes repletas de preconcepções. A autora faz um panorama do debate sobre prostituição dialogando com autoras árabes, brasileiras e muçulmanas, além de mostrar como no filme de Nabil Ayouch há um necessário rompimento com os estereótipos que cercam este tema. Por fim, também buscando o debate contemporâneo, Thayris de Oliveira e Ariel Finguerut reconstroem em ensaio a ascensão de Donald J. Trump de candidato outsider a presidente eleito dos Estados Unidos. Nesta trajetória os autores discutem a manipulação do medo, especialmente a islamofobia e a misoginia. Trump chega ao poder com uma estratégia populista manipulando temores, desqualificando os intelectuais, atacando os críticos e escolhendo como "bode expiatório" ora muçulmanos, ora latinos, ora negros, ora mulheres. Ao se alimentar da polarização política, Trump tenta destruir e ao mesmo tempo reconstruir a base eleitoral e ideológica do Partido Republicano.

Boa Leitura!

São Paulo, 14 de Setembro de 2017

Peter Robert Demant Editor-chefe da Revista Malala

Ariel Finguerut Membro do Conselho Científico da Revista Malala 